\title{
Comparative Toxicity of Five Pesticides Against Tetranychus urticae (Koch), Myzus persicae (Sulzer) and Aphis nerii (Boyer de Fonscolombe)
}

\author{
Entsar I. Rabea ${ }^{1}$
}

\begin{abstract}
Contact toxicity assay of chlorpyrifos, profenofos, deltamethrin, lambda-cyhalothrin and spinosad were tested against three species of arthropod pests; the twospotted spider mite Tetranychus urticae, the oleander aphid Aphis nerii and the green peach aphid Myzus persicae under laboratory conditions. The biological assessment was carried out using a slide-dip technique. The results of the acaricidal activity showed that lambdacyhalothrin and spinosad caused the highest toxicity against $T$. urticae with $\mathrm{LC}_{50}$ of 4.88 and $6.72 \mathrm{mg} . \mathrm{L}^{-1}$, respectively, followed by chlorpyrifos, deltamethrin and profenofos $\left(\mathrm{LC}_{50}=11.44,12.86\right.$ and $16.47 \mathrm{mg} . \mathrm{L}^{-1}$, respectively). Based on the toxicity index values, it is quite clear that the toxicity of lambda-cyhalothrin against $T$. urticae was 1.3 fold more toxic than spinosad and 2.3 and 2.6 fold more toxic than chlropyrifos and deltamethrin, respectively. The results of the aphicidal activity showed that deltamethrin has a high toxic effect against $A$. nerii and $M$. persicae with $\mathrm{LC}_{50}$ of 0.31 and $1.11 \mathrm{mg} . \mathrm{L}^{-1}$, respectively whereas, spinosad was the least toxic one $\left(L C_{50}=22.13\right.$ and 30.92 mg. $\mathrm{L}^{-1}$, respectively $)$. Based on the toxicity index, it is apparent that deltamethrin is the most potent compound against $A$. nerii followed by lambdacyhalothrin, chlorpyrifos, profenofos, and spinosad with toxicity index values of 100, 34.04, 3.95, 3.47 and 1.40 but followed by lambda-cyhalothrin, profenofos, chlorpyrifos and spinosad against $M$. persicae with toxicity index values of 100, 42.52, 27.61, 9.07 and 3.59, respectively. M. persicae was relatively more tolerant than $A$. nerii to profenofos, spinosad, chlorpyrifos, lambda-cyhalothrin and deltamethrin with tolerance level of $0.45,1.40,1.56,2.87$ and 3.58, respectively.
\end{abstract}

Key words: acaricidal activity, aphicidal activity, Tetranychus urticae, Aphis nerii, Myzus persicae

\section{INTRODUCTION}

Mites and aphids are considered the most important sucking pests that attacking agricultural crops (Taha et al., 2001, Slosser et al., 2002 and FAO, 2008). They cause a great damage through their feeding and draining of the plant sap from various plant parts. In addition to damages, they caused directly through feeding behavior, the sooty mold induced by the great amount of aphid honeydew (Butler and Henneberry, 1986, Harris et al., 1992, Bridges et al., 2001, Liu and Yue, 2001, Gray and Gildow, 2003 and Rana, 2005).

${ }^{1}$ Department of Pest Control and Environmental Protection; Faculty of Agriculture, Damanhour, Alexandria University, Egypt Received September 8, 2009, Accepted September 27, 2009
The two-spotted spider mite, Tetranychus urticae Koch (Acari: Tetranychidae) is a serious pest and responsible for significant yield losses in many horticultural, ornamental and agricultural crops including cotton, corn, soybeans and many orchard crops (Helle and Sabelis, 1985, Nachman and Zemek, 2002 and Zhang, 2003). It ingests leaf cell contents, thus reducing plant photosynthesis (Park and Lee, 2002), and potentially decreasing fruit quality and yield (Flaherty and Wilson, 1999). It causes direct effects include small spots on the upper side of the leaf due to chlorophyll depletion, webbing, defoliation; necrosis may occur in young leaves and stems or even the death of the plant (Brandenburg and Kennedy, 1987).

The peach-potato aphid Myzus persicae Sulzer (Hemiptera: Aphididae) is a small green aphid. It is the most significant aphid pest of peaches, cuasing shrivelling of the leaves and necrosis of various tissues. Moreover, it is a serious pest on a wide range of other agricultural and horticultural crops due to its ability to transmit virus diseases and to cause substantial direct damage (Foster et al., 2000). The oleander aphid Aphis nerii Boyer de Fonscolombe (Hemiptera: Aphididae), sometimes called the milkweed aphid, is a common pest of several ornamental plants in the families Apocynaceae and Asclepiadaceae. It is bright yellow with black legs and usually appears in late spring. It ingests sap from the phloem of its host plant and the damage caused by aphid colonies is mainly aesthetic due to the large amounts of sticky honeydew produced and the resulting black sooty mold that grows on the honeydew. In addition, the growing terminals can be deformed. It is able also to transmit several viruses including sugarcane mosaic and papaya ring spot potyvirus (Hall and Ehler, 1980 and Blackman and Eastop, 2000).

The control of aphid pests measures have largely been depending on the use of chemical pesticides including chlorinated hydrocarbons and organophosphates, carbamates (Blackman and Eastop, 2000, Shetlar, 2001 and Han and Li, 2004). However, the most widely used methods for controlling $T$. urticae are based on the application of natural and synthetic acaricides (Basta and Spooner-Hart, 2002, Chiasson et al., 2004, Choi et al., 2004 and Calmasur et al., 2006). 
One of the major problems in the control of such pests is their ability to rapidly develop resistance to many pesticides (Foster et al., 2000, Devine et al., 2001, Herron et al., 2001 and Li et al., 2003).

Therefore, this paper describes a laboratory study that assessed the potential of certain pesticides including two organophosphates (chlorpyrifos and profenofos), two pyrethroids (deltamethrin and lambdacyhalothrin) and a microbial pesticide (spinosad) against three species of arthropod pests; the two-spotted spider mite ( $T$. urticae), the oleander aphid (A. nerii) and the green peach aphid (M. persicae).

\section{MATERIALS AND METHODS}

\section{Tested compounds}

Five commercial pesticides were used and the dosages were calculated on the basis of active ingredient as $\mathrm{mg} . \mathrm{L}^{-1}$. Common names, trade names, chemical names and formulations for the tested insecticides are shown in Table 1.

\section{Test Pests}

Three species of arthropod pests tested in this study included the adult females of two-spotted spider mite $T$. urticae Koch (Acari: Tetranychidae), the oleander aphid A. nerii Boyer de Fonscolombe (Hemiptera: Aphididae) and the green peach aphid $M$. persicae Sulzer (Hemiptera: Aphididae). A colony of T. urticae was obtained from a culture maintained in Pesticide Chemistry Department, Faculty of Agriculture, Alexandria University and was reared on caster-oil plant Ricinus communis L., leaves and kept under laboratory conditions at $26 \pm 2{ }^{\circ} \mathrm{C}$ and $65 \pm 5 \%$ R.H. with a 12:12 light:dark photoperiod. Samples of $A$. nerii and $M$. persicae were collected from the infested plants of the peach orchard and oleander plants, respectively and tested directly without further rearing.

\section{Toxicity bioassay}

To measure the toxicity of the tested compounds against $T$. urticae, $A$. nerii and $M$. persicae, the FAO recommended slide-dip method with a little modification was used (Anonymous 1980). Twenty adult of the test aphid or mite were placed on their dorsum with a fine brush on a double-side adhesive tape on a glass slide. The insecticides were dissolved in distilled water to obtain a series of concentrations (ranged from 1 to $250 \mathrm{mg} . \mathrm{L}^{-1}$ ). The slides were dipped in a test solution for 5 seconds. Three replicates with three slides were maintained for each treatment and control. The slides were placed in a chamber at 26 $\pm 2{ }^{\circ} \mathrm{C}$ and $65 \pm 5 \%$ R.H., with a 12:12 light : dark photoperiod. Mortality was determined $24 \mathrm{~h}$ after treatment under a microscope and corrected mortality (\%) was calculated using Abbott's formula (Abbott, 1925). LC $_{50}$ values were calculated according to Finney (1971). Toxicity index of the tested compounds was determined according to Sun (1950) as follow:

Toxicity index $=\frac{\mathrm{LC}_{50} \text { of the most effective compound }}{\mathrm{LC}_{50} \text { of the tested compound }} \times 100$

The tolerance level for each compound against aphid species was calculated as follow:

Tolerance level $=\frac{\mathrm{LC}_{50} \text { value of } M \text {. persicae of any compound }}{\mathrm{LC}_{50} \text { value of } A \text {. nerii of the same compound }}$ Statistical analysis

Statistical analysis was performed by a SPSS software version 12.0 (Statistical Package for Social Sciences, USA). The values of $\mathrm{LC}_{50}$ were considered to be significantly different if the $95 \%$ confidence limits did not overlap.

\section{Table 1. The commercial pesticides used in bioassays}

\begin{tabular}{|c|c|c|c|}
\hline $\begin{array}{l}\text { Common } \\
\text { name }\end{array}$ & Trade name & Chemical name & Formulation \\
\hline Klorozd & Chlorpyrifos & $\begin{array}{l}O, O \text {-diethyl- } O \text {-(3,5,6-trichloro-2-pyridyl) } \\
\text { phosphorothioate }\end{array}$ & $48 \%$ EC (KZ Co.) \\
\hline Selean & Profenofos & $\begin{array}{l}O \text {-(4-bromo-2-chlorophenyl)- } O \text {-ethyl- } S \text {-propyl } \\
\text { phosphorothioate }\end{array}$ & $72 \%$ EC (KZ Co.) \\
\hline Kafrothrin & Deltamethrin & $\begin{array}{l}(S) \text { - } \alpha \text {-cyano-3-phenoxybenzyl }(1 R, 3 R)-3-(2,2- \\
\text { dibromovinyl)-2,2-dimethylcyclopropane carboxylate }\end{array}$ & $2.5 \%$ EC (KZ Co.) \\
\hline Lmdathrin & $\begin{array}{l}\text { Lambda- } \\
\text { cyhalothrin }\end{array}$ & $\begin{array}{l}(S) \text { - } \alpha \text {-cyano-3-phenoxybenzyl }(\mathrm{Z})-(1 R, 3 R)-3 \text {-(2-chloro- } \\
\text { 3,3,3-trifluoro-1-propenyl)-2,2-dimethylcyclopropane } \\
\text { carboxylate) }\end{array}$ & $5 \%$ EC (KZ Co.) \\
\hline Tracer & Spinosad & $\begin{array}{l}\text { a mixture of spinosyns A and D that are tetracyclic- } \\
\text { macrolide compounds produced by an actinomycete, } \\
\text { Saccharopolyspora spinosa }\end{array}$ & $\begin{array}{l}24 \% \text { SC (Dow } \\
\text { AgroSciences) }\end{array}$ \\
\hline
\end{tabular}




\section{RESULTS AND DISCUSSIONS}

\section{Acaricidal activity against $T$. urticae}

The data of the acaricidal activity of the tested insecticides against $T$. urticae are presented in Table 2. Based on the $\mathrm{LC}_{50}$ values, all of the compounds showed a varied degree of the toxicity. Lambda-cyhalothrin, as a pyrethroid, caused the highest acaricidal activity $\left(\mathrm{LC}_{50}\right.$ $=4.88 \mathrm{mg} \cdot \mathrm{L}^{-1}$ ) followed by spinosad, chlropyrifos, deltamethrin and profenofos $\left(\mathrm{LC}_{50}=6.72,11.44,12.86\right.$ and $16.47 \mathrm{mg} . \mathrm{L}^{-1}$, respectively). Concerning on the toxicity index values (Table 2), it is quite clear that the toxicity of lambda-cyhalothrin against $T$. urticae was 1.3 fold more toxic than spinosad and 2.3 and 2.6 fold more toxic than chlropyrifos and deltamethrin, respectively. While the toxicity of lambda-cyhalothrin was 3.3 fold more toxic than profenofos.

The current results are in agreement with the previous finding of many investigators. For example, McKee and Knowles, (1985) reported that FMC-54800 [1,1'-biphenyl-3yl methyl cis-3-(2-chloro-3,3,3trifluoro-1-propenyl)-2,2-dimethyl cyclopropane carboxylate], as a pyrethroid, gave the most toxic effect to $T$. urticae based on both respiration and mortality studies, while permethrin, fenvalerate and fluvalinate were intermediate in pharmacokinetic efficiency. Marshall and Pree, (1991) found that the fenpropathrin at the field rate, was highly toxic to nymphs and adults of the European red mite Panonychus ulmi (Koch) at 48 h where 98 and $100 \%$ of the $P$. ulmi nymphs and adults were killed, respectively. Recently, Ismail et al., (2006) studied the effect of cypermethrin against $T$. urticae on three different host plants (castor bean, green bean and tomato) using leaf disc dip technique. They found that cypermethrin has a moderate toxic effect on the three host plants discs with $\mathrm{LC}_{50}$ of 166.9, 139.7 and 122.9 ppm for castor bean, green bean and tomato, respectively.
Our result also indicated that, chlorpyrifos has a moderate toxic effect $\left(\mathrm{LC}_{50}=11.44 \mathrm{mg} \cdot \mathrm{L}^{-1}\right)$ on the adult females of $T$. urticae comparing to the other insecticides. El-Khodary et al., (2007) evaluated the toxicity of fenitrothion as an organophosphate, against the adult females of $T$. urticae under laboratory conditions. They found that fenitrothion has toxic effect against $T$. urticae with an $\mathrm{LC}_{50}$ of $411.22 \mathrm{ppm}$.

Spinosad is a novel insect control agent derived by fermentation of the actinomycete bacterium, Saccharopolyspora spinosa. The active ingredient is composed of two variants, spinosyn A and spinosyn D (Thompson et al., 2000). Spinosad controls many caterpillar pests in some fruit and vegetables, thrips in tomatoes, peppers and ornamental cultivation and dipterous leaf miners in vegetables and ornamentals (Miles, 2003). Our results indicated that spinosad showed a high contact acaricidal activity against $T$. urticae $\left(\mathrm{LC}_{50}=6.72 \mathrm{mg} \cdot \mathrm{L}^{-1}\right)$. DeAmicis et al., (1997) reported that this compound caused $100 \%$ mortality when applied directly to $T$. urticae at $400 \mathrm{ppm}$. ElKhodary et al., (2007) added that biofly (Beauvaria bassiana) and agerin (Bacillus thuringiensis) as biopesticides were effective against the adult female of T. urticae with $\mathrm{LC}_{50}$ of 57857.8 conidia/ml and 103.2 ppm, respectively.

\section{Aphicidal activity against $A$. nerii and $M$. persicae}

The acute toxicity of chlorpyrifos, profenofos, deltamethrin, lambda-cyhalothrin and spinosad against A. nerii and M. persicae was examined under laboratory condition after $24 \mathrm{~h}$ and the data are shown in Tables 3 and 4 , respectively. The results of A. nerii (Table 3) showed that the deltamethrin and lambda-cyhalothrin were the most toxic insecticides $\left(\mathrm{LC}_{50}=0.31\right.$ and 0.91 $\mathrm{mg} . \mathrm{L}^{-1}$, respectively). Chlorpyrifos and profenofos, as organophosphates, were moderately toxic $\left(\mathrm{LC}_{50}=7.84\right.$ and $8.94 \mathrm{mg} . \mathrm{L}^{-1}$, respectively). However, spinosad was the least active one compared to the others $\left(\mathrm{LC}_{50}=\right.$ $22.13 \mathrm{mg} \cdot \mathrm{L}^{-1}$ ).

Table 2. Toxicity of chlorpyrifos, profenofos, deltamethrin, lambda-cyhalothrin and spinosad to the adult females of $T$. urticae after $24 \mathrm{~h}$ of treatment

\begin{tabular}{|c|c|c|c|c|c|c|c|}
\hline \multirow{2}{*}{ Insecticide } & \multirow{2}{*}{$\begin{array}{c}\mathbf{L C}_{50} \\
\left(\mathbf{m g} . \mathrm{L}^{-1}\right)\end{array}$} & \multicolumn{2}{|c|}{$\begin{array}{l}95 \% \text { confidence } \\
\text { limits }\left(\text { mg. }^{-1}\right)\end{array}$} & \multirow{2}{*}{$\begin{array}{c}\text { Slope } \pm \\
\text { SE }\end{array}$} & \multirow{2}{*}{$\begin{array}{c}\text { Intercept } \\
\pm \text { S.E }\end{array}$} & \multirow{2}{*}{$\begin{array}{c}\text { Chi } \\
\text { square } \\
\left(\chi^{2}\right)\end{array}$} & \multirow{2}{*}{$\begin{array}{c}\text { Toxicit } \\
y \\
\text { index* }\end{array}$} \\
\hline & & Lower & Upper & & & & \\
\hline Chlorpyrifos & 11.44 & 5.17 & 18.16 & $0.75 \pm 0.13$ & $-0.79 \pm 0.2$ & 0.02 & 42.66 \\
\hline Profenofos & 16.47 & 1.56 & 33.09 & $1.04 \pm 0.30$ & $-1.27 \pm 0.61$ & 0.03 & 29.63 \\
\hline Deltamethrin & 12.86 & 8.43 & 17.50 & $1.37 \pm 0.16$ & $-1.52 \pm 0.26$ & 0.02 & 37.95 \\
\hline Lambda-cyhalothrin & 4.88 & 2.49 & 7.26 & $1.68 \pm 0.25$ & $-1.15 \pm 0.34$ & 0.85 & 100 \\
\hline Spinosad & 6.72 & 3.10 & 9.79 & $1.47 \pm 0.29$ & $-1.22 \pm 0.39$ & 0.85 & 72.62 \\
\hline
\end{tabular}

*Toxicity index was calculated with respect to Lambda-cyhalothrin as the most effective compound 
Table 3. Toxicity of chlorpyrifos, profenofos, deltamethrin, lambda-cyhalothrin and spinosad against the $A$. nerii after $24 \mathrm{~h}$ of treatment

\begin{tabular}{|c|c|c|c|c|c|c|c|}
\hline \multirow[t]{2}{*}{ Insecticide } & \multirow{2}{*}{$\begin{array}{c}\mathbf{L C}_{50} \\
\left(\mathrm{mg} \mathbf{L}^{-1}\right)\end{array}$} & \multicolumn{2}{|c|}{$\begin{array}{l}95 \% \text { confidence } \\
\text { limits }\left(\mathrm{mg.L}^{-1}\right)\end{array}$} & \multirow{2}{*}{$\begin{array}{l}\text { Slope } \pm \\
\text { SE }\end{array}$} & \multirow{2}{*}{$\begin{array}{l}\text { Intercept } \\
\quad \pm \text { S.E }\end{array}$} & \multirow{2}{*}{$\begin{array}{c}\text { Chi } \\
\text { square } \\
\left(\chi^{2}\right)\end{array}$} & \multirow{2}{*}{$\begin{array}{l}\text { Toxicity } \\
\text { index* }\end{array}$} \\
\hline & & Lower & Upper & & & & \\
\hline Chlorpyrifos & 7.84 & 5.69 & 10.12 & $0.99 \pm 0.12$ & $-0.85 \pm 0.12$ & 1.22 & 3.95 \\
\hline Profenofos & 8.94 & 6.33 & 12.99 & $0.87 \pm 0.11$ & $-0.82 \pm 0.12$ & 0.17 & 3.47 \\
\hline Deltamethrin & 0.31 & 0.07 & 0.66 & $0.83 \pm 0.14$ & $-0.42 \pm 0.12$ & 0.16 & 100 \\
\hline Lambda-cyhalothrin & 0.91 & 0.13 & 2.09 & $0.45 \pm 0.11$ & $-0.02 \pm 0.11$ & 0.10 & 34.07 \\
\hline Spinosad & 22.13 & 15.80 & 28.60 & $1.14 \pm 0.18$ & $-1.54 \pm 0.27$ & 1.11 & 1.40 \\
\hline
\end{tabular}

* Toxicity index was calculated with respect to deltamethrin as the most effective compound

Based on the toxicity index values (Table 3), it is apparent that deltamethrin was the most potent compound against $A$. nerii followed by lambdacyhalothrin with toxicity index values of 100 and 34.07, respectively. While chlorpyrifos and profenofos were slightly less toxic compounds with toxicity index of 3.95 and 3.47, respectively. However, spinosad was the least active one with a toxicity index of 1.40.

The data of the toxicity of the tested insecticides against $M$. persicae is presented in Table 4 showed that deltamethrin was also significantly the most toxic among the insecticides tested with $\mathrm{LC}_{50}$ of $1.11 \mathrm{mg} . \mathrm{L}^{-1}$, followed by lambda-cyhalothrin and profenofos $\left(\mathrm{LC}_{50}=\right.$ 2.61 and $4.02 \mathrm{mg} . \mathrm{L}^{-1}$, respectively). However, chlorpyrifos proved to be slightly less toxic $\left(\mathrm{LC}_{50}=\right.$ $\left.12.23 \mathrm{mg} . \mathrm{L}^{-1}\right)$ and spinosad was the least toxic one $\left(\mathrm{LC}_{50}=30.92 \mathrm{mg} . \mathrm{L}^{-1}\right)$.

Table 4. Toxicity of chlorpyrifos, profenofos, deltamethrin, lambda-cyhalothrin and spinosad against the $M$. persicae after $24 \mathrm{~h}$ of treatment

\begin{tabular}{|c|c|c|c|c|c|c|c|}
\hline \multirow[t]{2}{*}{ Insecticide } & \multirow[t]{2}{*}{$\begin{array}{c}\mathbf{L C}_{50} \\
\left(\mathrm{mg} \cdot \mathrm{L}^{-1}\right)\end{array}$} & \multicolumn{2}{|c|}{$\begin{array}{l}\text { 95\% confidence limits } \\
\left(\mathrm{mg.L}^{-1}\right)\end{array}$} & \multirow{2}{*}{$\begin{array}{l}\text { Slope } \pm \\
\text { SE }\end{array}$} & \multirow{2}{*}{$\begin{array}{l}\text { Intercept } \\
\quad \pm \text { S.E }\end{array}$} & \multirow{2}{*}{$\begin{array}{c}\text { Chi } \\
\text { square } \\
\left(\chi^{2}\right)\end{array}$} & \multirow{2}{*}{$\begin{array}{l}\text { Toxicity } \\
\text { index* }\end{array}$} \\
\hline & & Lower & Upper & & & & \\
\hline Chlorpyrifos & 12.23 & 5.70 & 25.9 & $0.96 \pm 0.08$ & $-1.05 \pm 0.12$ & 3.95 & 9.07 \\
\hline Profenofos & 4.02 & 2.95 & 5.25 & $1.14 \pm 0.10$ & $-0.69 \pm 0.11$ & 3.47 & 27.61 \\
\hline Deltamethrin & 1.11 & 0.54 & 1.80 & $0.82 \pm 0.09$ & $-0.04 \pm 0.11$ & 100 & 100 \\
\hline Lambda-cyhalothrin & 2.61 & 1.93 & 3.37 & $1.11 \pm 0.11$ & $-0.46 \pm 0.10$ & 34.07 & 42.52 \\
\hline Spinosad & 30.92 & 21.65 & 42.95 & $0.92 \pm 0.81$ & $-1.36 \pm 0.27$ & 1.40 & 3.59 \\
\hline
\end{tabular}

*Toxicity index was calculated with respect to deltamethrin as the most effective compound

Table 5. $\mathrm{LC}_{50}$ values and the tolerance levels for $A$. nerii and $M$. persicae of the tested insecticides

\begin{tabular}{|c|c|c|c|}
\hline Insecticide & $\begin{array}{c}\mathrm{LC}_{50}\left(\mathrm{mg} \mathrm{L}^{-1}\right) \text { for } \\
\text { A. nerii }\end{array}$ & $\begin{array}{c}\mathrm{LC}_{50}\left(\mathrm{mg} \mathrm{L}^{-1}\right) \text { for } \\
\text { M. persicae }\end{array}$ & $\begin{array}{c}\text { Tolerance level }^{*} \\
\left(\mathrm{LC}_{50} \text { ratio }\right)\end{array}$ \\
\hline Chlorpyrifos & 7.84 & 12.23 & 1.56 \\
\hline Profenofos & 8.94 & 4.02 & 0.45 \\
\hline Deltamethrin & 0.31 & 1.11 & 3.58 \\
\hline Lambda-cyhalothrin & 0.91 & 2.61 & 2.87 \\
\hline Spinosad & 22.13 & 30.92 & 1.40 \\
\hline
\end{tabular}
data revealed that deltamethrin was the highly toxic compound against $M$. persicae with a toxicity index of 100 followed by lambda-cyhalothrin with a toxicity index of 42.52. However, profenofos has a moderate toxic action with a toxicity index of 27.61. In addition, spinosad was the least toxic one with toxicity index of In addition, the tolerance level for each compound was calculated by dividing the $\mathrm{LC}_{50}$ value of $M$. persicae of any compound by the $\mathrm{LC}_{50}$ value of $A$. nerii of the same compound and the data are presented in Table 5. The data indicated that $M$. persicae was relatively more tolerant than $A$. nerii to profenofos, spinosad, chlorpyrifos, lambda-cyhalothrin and deltamethrin with tolerance levels of $0.45,1.40,1.56$, 2.87 and 3.58 , respectively.

Tolerance level $=\mathrm{LC}_{50}$ of $M$. persicae $/ \mathrm{LC}_{50}$ of A. nerii 
From Tables 3 and 4, it can be noticed that deltamethrin and lambda-cyhalothrin had a highly toxic effect against the two species of aphids since $\mathrm{LC}_{50}$ were 0.31 and $0.91 \mathrm{mg} . \mathrm{L}^{-1}$ against $A$. nerii and 1.11 and 2.61 mg. $\mathrm{L}^{-1}$ against $M$. persicae, respectively. Moreover, spinosad was the least toxic compound against the two aphid species used in this study. Our results showed that pyrethroids insecticides (deltamethrin and lambdacyhalothrin) were more toxic than organophosphates insecticides (chlorpyrifos and profenofos) against the two tested aphid species. These results can be supported with those obtained by several investigators. For example, Khalequzzaman and Nahar, (2008) reported that the cypermethrin, as a pyrethroid, was the most toxic compound against aphids of A. craccivora, A. gossypii, M. persicae and Lipaphis erysimi showing $\mathrm{LC}_{50}$ as 12.55, 12.29, 12.55 and $12.10 \mu \mathrm{g} . \mathrm{cm}^{-2}$, respectively. While, malathion, as an organophosphate, was the least toxic having $\mathrm{LC}_{50}$ of 327.97 , 333.92, 305.26 and $313.77 \mu \mathrm{g} . \mathrm{cm}^{-2}$ for A. craccivora, $A$. gossypii, $M$. persicae and $L$. erysimi, respectively. Mohamed et al., (2006) investigated the pesticidal efficiency of Actellic [pirimiphos-methyl] at recommended rate of $385 \mathrm{~cm}^{3} / 100 \mathrm{~L}$ and $38.5 \mathrm{~cm}^{3} / 100$ $\mathrm{L}$ against cabbage aphid (Brevicoryne brassicae) by spraying on highly infested cabbage plants and they found that this compound at the full recommended rate $\left(385 \mathrm{~cm}^{3} / 100 \mathrm{~L}\right)$ showed the highest efficacy against $B$. brassicae. In addition, El-Khodary et al., (2007) reported that fenitrothion had a high toxic effect against A. gossypii with an $\mathrm{LC}_{50}$ value of $1.66 \mathrm{ppm}$.

When we consider the susceptibility of the aphids to the tested insecticides in our study, another point deserves attention; these compounds were more toxic on $A$. nerii than $M$. persicae as shown in Table 5 by tolerance levels. The obtained results are in agreement with those of Khalequzzaman and Nahar, (2008) who reported that azadirachtin had $\mathrm{LC}_{50}$ of $0.34 \mu \mathrm{g} . \mathrm{cm}^{-2}$ for A. gossypii and $0.44 \mu \mathrm{g} . \mathrm{cm}^{-2}$ for $M$. persicae. However, cypermethrin, as a pyrethroid, had $\mathrm{LC}_{50}$ of 12.29 and $12.55 \mu \mathrm{g} . \mathrm{cm}^{-2}$ against A. gossypii and M. persicae, respectively.

\section{CONCLUSION}

The acute toxicity of chlorpyrifos, profenofos, deltamethrin, lambda-cyhalothrin and spinosad was tested against $T$. urticae, $A$. nerii and $M$. persicae using a slide-dip technique. The results of the acaricidal activity indicated that lambda-cyhalothrin and spinosad caused the highest toxicity against $T$. urticae followed by chlorpyrifos, deltamethrin and profenofos. Based on the toxicity index values, it was quite clear that the toxicity of lambda-cyhalothrin against $T$. urticae was
1.3 fold more toxic than spinosad and 2.3 and 2.6 fold more toxic than chlropyrifos and deltamethrin, respectively. The results of aphicidal activity showed that deltamethrin has a special position in aphid chemical control because of its high toxic effect and its high toxicity index against $A$. nerii and $M$. persicae. Based on the tolerance level, $M$. persicae was relatively more tolerant than $A$. nerii to profenofos, spinosad, chlorpyrifos, lambda-cyhalothrin and deltamethrin, respectively.

\section{REFERENCES}

Abbott, W. S. (1925). A method for computing the effectiveness of an insecticide. J. Econ. Entomol., 18: 265267.

Annonymous (1980). Plant production and protection 21, recommended methods for measurement of resistance to pesticide. FAO, Israel. 49-54.

Basta, A. and R. N. Spooner-Hart (2002). Efficacy of an extract of Dorrigo pepper against two-spotted mite and greenhouse thrips. pp 471-476. In GAC Beattie, D. M. Watson, M. L. Stevens, D. J. Rae, R. N. Spooner-Hart [eds.], Spray oils beyond 2000, 25-29 October 1999. Sydney, NSW, Australia. University of Western Sydney, Australia.

Blackman, R. L. and V. F. Eastop (2000). Aphids on the World's Crops: An Identification and Information Guide, 2nd ed. John Wiley \& Sons Ltd., Chichester. p. 466.

Brandenburg, R. L. and G. G. Kennedy (1987). Ecological and agricultural considerations in the management of twospotted spider mite (Tetranychus urticae Koch). Agric. Zool. Rev., 2: 185-236.

Bridges, M.; M. E. Jones; A. M. Bones; C. Hodgson; R. Cole; E. Bartlet; V. Wallsgrove; K. V. Karapapa; N. Watts and J. T. Rossiter (2001). Spatial organization of the glucosinate-myrosinase system in brassica specialist aphids is similar to that of the host plant. Proc. R. Soc. Lond. Ser., B 233: 1-5.

Butler, G. D. and T. J. Hennebrerry (1986). Effect of cotton seedling infestation by cotton leaf crumple virus on subsequent growth and yield. J. Econ. Entomol., 79: 208211.

Calmasur, O.; I. Aslan and F. Sahin (2006). Insecticidal and acaricidal effect of three Lamiaceae plant essential oils against Tetranychus urticae Koch and Bemisia tabaci Genn. Indust. Crops Prod., 23: 140-146.

Chiasson, H.; N. J. Bostanian and C. Vincent (2004). Acaricidal properties of a chenopodium-based botanical. J. Econ. Entomol., 97: 1373-1377.

Choi, W. I.; S. G. Lee; H. M. Park; and Y. J. Ahn (2004). Toxicity of plant essential oils to Tetranychus urticae (Acari: Tetranychidae) and Phytoseiulus persimilis (Acari: Phytoseiidae). J. Econ. Entomol., 97: 553-558.

DeAmicis, C. V.; J. E. Dripps; C. J. Hatton and L. L. Karr (1997). Phytochemicals for pest control. Am. Chem. Soc. J., 658: 144-154. 
Devine, G. J.; M. Barber and I. Denholm (2001). Incidence and inheritance of resistance to METI-acaricides in European strains of the two-spotted spider mite (Tetranychus urticae) (Acari: Tetranychidae). Pest Manag. Sci., 57: 443-448.

El-Khodary. A. S.; M. Samy; A. Y. Keratum and S. K. M. ElFakharany (2007). Toxicity of some pesticides and oil plant extracts to plant sucking pests. Pest Cont. Environ. Sci., 15: 49-61.

FAO (2008). Provisional 2004_Production Data._Agricultural production, crops primạry. hittp:///apps.fao.org/faostat Status: 09.2008.

Finney, D. J. (1971) Probit Analysis, 3rd Edition. Cambridge University Press, London, UK.

Flaherty, D. L. and L. T. Wilson (1999). Biological control of insects and mites on grapes. In: Bellows, T.S., Fisher, T.W. (Eds.), Handbook of Biological Control. Academic Press, New York, USA, pp. 853-869.

Foster, S. P.; I. Denholm and A. L. Devonshire (2000). The ups and downs of insecticide resistance in peach-potato aphids (Myzus persicae) in the UK. Crop Prot., 19: 873879.

Gray, S. M. and F. Gildow (2003). Luteovirus-Aphid Interactions. Ann. Rev. Phytopathol., 41: 539-566.

Hall, R. W. and L. E. Ehler (1980). Population ecology of Aphis nerii on oleander. Environ. Entomol., 9: 338-344.

Han, Z and F. Li (2004). Mutations in acetylcholinesterase associated with insecticide resistance in the cotton aphid, Aphis gossypii Glover. Insect Biochem. Mol. Biol., 34: 397-405.

Harris, F. A.; G. L. Andrews; D. F. Gaillave and R. E. Furr (1992). Cotton aphid effect on yield, quality and economics of cotton. p. 652-656. In proceeding Beltwide cotton production and Res. Conf. Nashville, TV, National cotton of America, Memphis, TN.

Helle, W. and M. W. Sabelis (1985). Spider mites: their biology, natural enemies and control. Vol. 1B. Elsevier Amsterdam.

Herron, G. A.; K. Powis and J. Rophail (2001). Insecticide resistance in Aphis gossypii Glover (Hemiptera: Aphididae), a serious threat to Australian cotton. Aust. J. Entomol., 40: 85-91.

Ismail, A. A.; W. H. Hegazi; A. S. Derbalah; N. E. Hasan and S. A. Hamed (2006). Toxicological and biological studies of some compounds against the two-spotted spider mite Tetranynchus urticae and its predatory mite, Amblyseius gossypii on different host plants. Pest Cont. Environ. Sci., 14: 227-256.

Khalequzzaman, M. and J. Nahar (2008). Relative toxicity of some insecticides and azadirachtin against four crop infesting aphid species. Univ. J. Zool. Rajshahi Univ., 27: 31-34.

Li, F.; H. ZhaoJun and T. Bo (2003). Insensitivity of acetylcholinesterase and increased activity of esterase in the resistant cotton aphid, Aphis gossypii Glover. ActaEntomol. Sinica., 46: 578-583.
Liu, T. and B. Yue (2001). Comparison of some life history parameters between alate and apterous forms of turnip aphid (Homoptera: Aphididae) on cabbage under constant temperatures. Florida Entomol., 84: 239-242.

Marshall, D. B. and D. J. Pree (1991). Effects of miticides on the life stages of the European red mite, Panonychus ulmi (Koch) (Acari: Tetranychidae). Candian Entomol., 123: 77-87.

McKee, M. J. and C. O. Knowles (1985). Pharmacokinetics of pyrethroids in two-spotted spider mites. Pest. Biochem. Physiol., 24: 326-335.

Miles, M. (2003). The effects of spinosad, a naturally derived insect control agent to the honeybee. Bull. Insectol., 56: 119-124.

Mohamed, S. A.; G. M. Mousa and A. G. El-Sisi (2006). Pesticidal efficiency of the mineral oil CAPL-2 alone or mixed with Actellic against cabbage aphid Brevicoryne brassicae L. and cotton leafworm Spodoptera littoralis (Boisd.) attacking cabbage plants. Egypt. J. Agric. Res., 84: 75-81.

Nachman, G. and R. Zemek (2002). Interactions in a tritrophic acarine predator-prey metapopulation system III: Effects of Tetranychus urticae (Acari: Tetranychidae) on the host plant condition. Exp. Appl. Acarol., 25: 27-42.

Park, Y. L. and J. H. Lee (2002). Leaf cell and tissue damage of cucumber caused by two-spotted spider mite (Acari: Tetranychidae). J. Econ. Entomol., 95: 952-957.

Rana, J. S. (2005). Performance of Lipaphis erysimi (Homoptera: Aphididae) on different Brassica species in a tropical environment. J. Pest. Sci., 78: 155-160.

Shetlar, D. J. (2001). Aphids on trees and shrubs, HYG-203190. Ohio State University Extension Fact sheet. Department of Horticulture and Crop Science. Ohio State University, USA

Slosser, J. E.; M. N. Parajulee; D. L. Hendrix; T. J. Henneberry and D. R. Rummel (2002). Relationship between Aphis gossypii (Homoptera: Aphididae) and sticky lint in cotton. J. Econ. Entomol., 95: 299-306.

Sun, Y. P. (1950). Toxicity index-an improved method of comparing the relative toxicity of insecticides. J. Econ. Entomol., 43: 45-53.

Taha, H. A.; S. M. Soliman; A. Abd El-Haleam and S. A. ElRaies (2001). Field studies on the main pests infesting cotton with refer to their natural enemies. Proceeding Beltwide Cotton Conf. National Cotton Council, Memphis T. N., 2: 885-888.

Thompson, G. D.; R. Dutton and T. C. Sparks (2000). Spinosad -a case study: an example from a natural products discovery programme. Pest Manag. Sci., 56: 696702.

Zhang, Z. (2003). Mites of Greenhouses: Identification, Biology and Control, CABI Publishing, Wallingford, p. 54-61. 


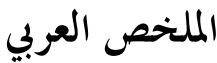

السمية النسبية لحمس مبيدات ضد الإناث البالغة للعنكبوت الأمر (تترانيكس يورتيكا) ومن التفلة (افيس نرياى) ومن الحوخ)(ميزس برسيكال

$$
\text { إنتصار إبراهيم ربيع }
$$

تم دراسة التأثير السام بالملامسة لبعض المبيدات مثل: المبل:

حيث كانت قيمة التركيز الذى يقتل •0\% من الأفراد المعاملة هى 1ا

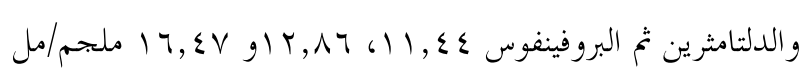
على التو الى. و لد

ومن ناحية التأثير الإبادى الحشرى ضد المن كان مبان مبيد

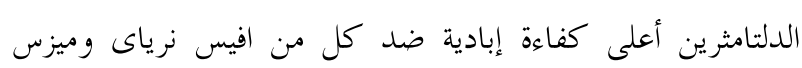

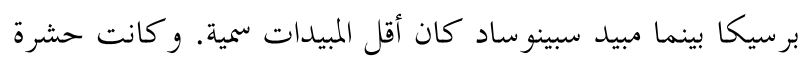
ميزس برسيكا أكثر تحملا من افيس نرياى بالنسبة للمبيدات البروفينفوس وسبينوساد و كلوربيريفوس و واللامداسيالوثرين

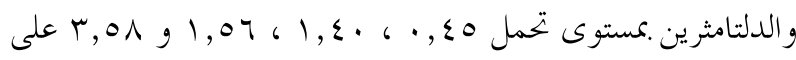

التوالى. - n

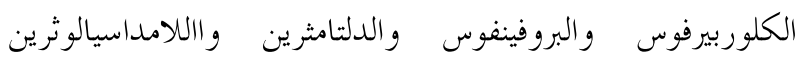
والمركب الطبيعى سبينوساد وذلك ضد بعض الآلفات الماصة الحيوانية والحشرية مثل الإناث البالغة للعنكبوت الأحمر (تترانيكس ونس الإنس

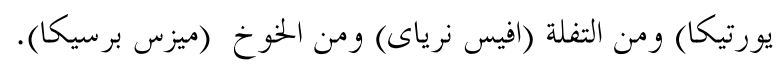

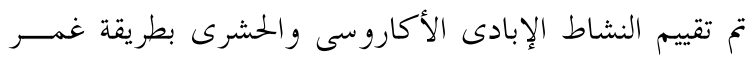

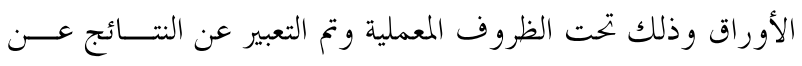

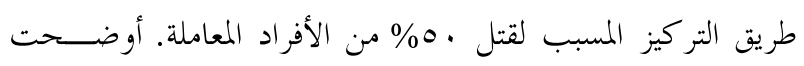

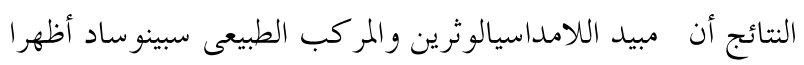

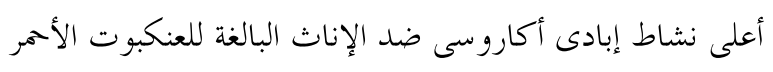


